\title{
Towards Five Star Classification Shopping Centre in Malaysia: An Exploratory Research on Categories of Shopping Centre
}

\author{
Ihfasuziella Ibrahim,Abdul HadiNawawi, Edie EzwanMohdSafian
}

\begin{abstract}
Shopping Centre is the most wonderful spots nowadays with their appealing shops and a wide assortment individual spend their free occasions to unwind, shop and make the most of their occasions. Be that as it may, it shows up the powers driving retail development everywhere throughout the world have withdrawn from real customers request. A shopping centre is a group of retail stores. With the harried number development of shopping centres in Malaysia, the competition among of those commercial retailers is seen as crucial. The shopping centre springing up around us like mushrooms after the rain. The changes format of urbanisation, globalisation, new technologies and innovations are leading the entire retail market makes our shopping centres management more challenging. Because shopping centres comprise of many types with different features to serve its function, the measurement of the quality of shopping centres becomes more complex. One of the ways to facilitate the measurement of quality of different types of shopping centres is by classifying the shopping centres. Therefore, this paper looks on the category the shopping centre in Malaysia based on physical criteria, rental rate, tenant's revenues and retails customers patronage satisfaction. The criteria of shopping centre acquired through literatures can be filled in as an orientation in making a categorised of shopping centres in Malaysia. Interview with government and private sectors involved in shopping centres has been conducted to find out the suitable category of shopping centre in Malaysia. This is an initial study toward the classification of shopping centres in Malaysia. Noted that the classification is very important for investment purpose and as a guideline, therefore, shopping centre must get a better rating tool for the developers and investors for their investment decision in the future.
\end{abstract}

Keywords: Classification, Shopping Centre, criteria, categorize, investment

\section{INTRODUCTION}

Investment in retail property is wide range from a smaller retail centres to large retail centres. The retail property market including small neighbourhood shopping centre and big outlet shopping centres. The main importance for retail centre investors is tenants and the purchasing power of customers can be an attraction to shopping centres.

Thus, investing in retail property needs a wide base of knowledge and experience in the regional economy. The all locational factors are vital because it can effect on the property as well the retail specific characteristics. The understanding of retail tenants in corporate real estate activities is of utmost vital as much time and resources are being spent on evaluating potential investments. [2].

Revised Manuscript Received on September 14, 2019.

Ihfasuziella Ibrahim,Faculty of Architecture, Planning and Surveying, UiTM, ShamAlam, Malaysia. (Email: hfasuziella.ibrahim@yahoo.com)

Abdul HadiNawawi, Faculty of Architecture, Planning and Surveying, UiTM, ShamAlam, Malaysia.

Edie EzwanMohdSafian, Faculty of Technology Management \& Business, UTHM, Johor, Malaysia
According to [2] also, the retail tenants may contrast in the management, size, sales, consumer types or trends and in their positions in the market and additionally positions towards their rivals.

These days consumers ordinarily demonstrated an inclination to shop at shopping centres due to the wide scope of items are offering under one rooftop and in the meantime offer understanding and engaging condition. The city of Kuala Lumpur was recognized as fourth best shopping city on the planet behind London, Tokyo and New York [3]. The choice for the four areas depended on 1-to-10 scoring scale for every class namely, value, getting around, assortment as well as experience. In a roundabout way, this circumstance demonstrated how the shopping centre is a huge advancement for the consumers in Malaysia. The advancement of shopping centres in Malaysia began with the opening of the Weld Supermarket in Jalan Raja Chulan (beforehand Weld Road) in 1963. Then, several shopping centres were developed, there were Emporium Selangor, Globe Silk Store, Yuyi Emporium, and Batu Road Supermarket. These entire shopping centres began their early development as neighbourhood centres. Based on annual World's Bank Current definition of high income threshold, the government unveiled an Economic Transformation Program (ETP) RM48,000 or USD15,000 per capita income in 2020. Therefore, to achieving high income status by 2020 is a requirement of annual real growth rate 6 percent in the next 10 years. The government's objective of high income is not only just a quantitative target. Government also hoped that Malaysia becoming an advanced, developed nation with an economy possessing the characteristics of a high-income economy, such as a thriving services sector, a balance between private consumption and investment as well as productivity levels that are similar to those of regional leaders. Klang Valley and the Greater Kuala Lumpur are presently doled out as the National Growth Conurbation (NGC) to fill in as a global exchanging focal point of the nation. Therefore, shopping centres is important component of NGC retail sector and will be playing catalyst role in the years leading to 2020 . [10]. About 115.5 million tourist's receipts was recorded and RM34.7 billion within the domestic segment. Additionally, Traveler Magazine (USA) recognized Malaysia as second place in the ranking of Best International Tourism Destination (2009 and 2010) and picked the best in Travel 2010. [4] has recorded the Kuala Lumpur is currently known as one of the 31 suggested traveller goals on the planet. 


\section{TOWARDS FIVE STAR CLASSIFICATION SHOPPING CENTRE IN MALAYSIA: AN EXPLORATORY RESEARCH ON CATEGORIES OF SHOPPING CENTRE}

Because shopping centres comprise of many types with different features to serve its function, the measurement of quality of shopping centres becomes more complex. One of the ways to facilitate the measurement of quality of different types of shopping centres is by classifying the shopping centres. The classification of shopping complex is challenging because shopping centres have different characteristics and subjected to innovation to maintain their attractiveness and hence competitiveness. The variables that are important in determining their classification include location, quality of public transportation, affordability of cabs, range of shopping categories, quantity of shops, quality of window displays and shop décor, dining and accommodation options, amenities and others [18]. Because of the complexity, investors face difficulties in making investment decision in shopping complex. Based on survey to stakeholders of shopping centre in Malaysia, there are $80 \%$ respondents agreed the classification of shopping centre importance and needed in Malaysia. The survey also proved that $90 \%$ respondents agreed if the rental offered in accordance with level of quality provided in a shopping centre in Malaysia.

\section{METHODOLOGY}

\subsection{Definition of Shopping Centre by Retailers}

To date, there are no specific globally recognized standards and guidelines in differentiating the usage of terminologies such as shopping mall, shopping center and shopping complex. According to the International Council of Shopping Centers [6], the definition of shopping centre is as a purpose-built retail centre with a number of retail lots within shared amenities and services such as airconditioning in common areas, car parking and others. It usually owned by one owner or landlord. Retail lots may be sold or let to individual owners on a strata basis. Survey on practitioners of shopping centre in government and private sector in Malaysia shows the different definition on shopping centre. There are seven (5) main issues in definition of shopping centre such as management, trading activities, parking lots, safety $\&$ health and anchor tenants

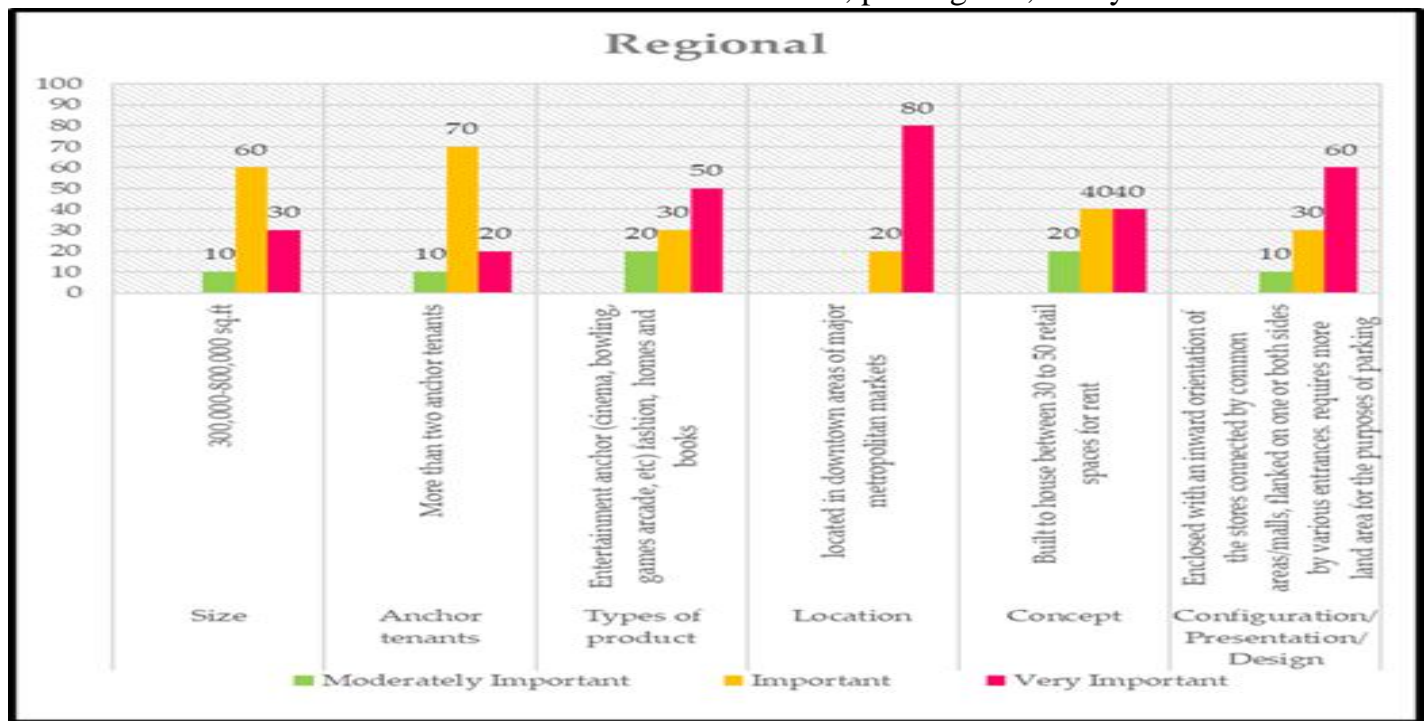

Fig.1 Super Regional Shopping Centre
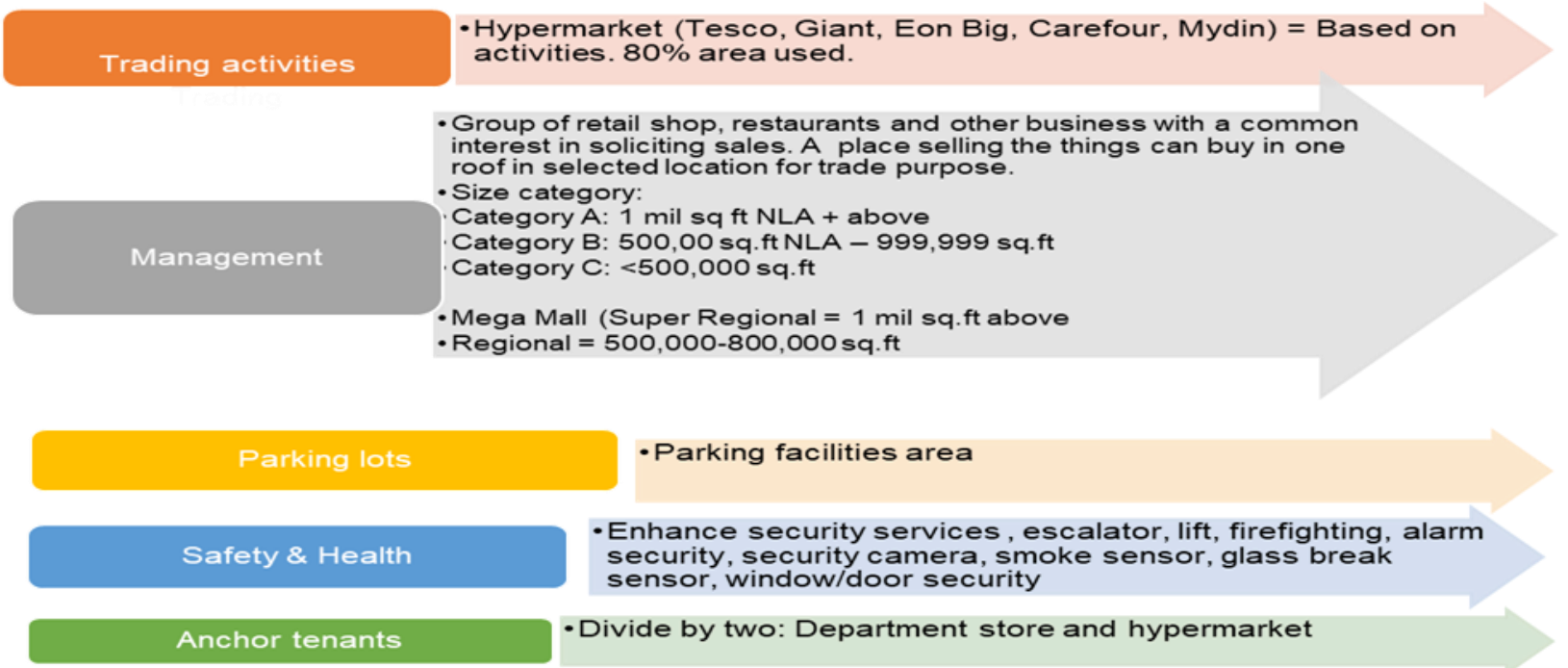

Fig.1 shows the differentiation definition shopping centre by practitioners in government and private sector 


\subsection{Categories of Shopping Centre}

There is a wide variety of shopping centres on the planet. Distinctive classes of shopping centres have some unique highlights since they are worked to address the issues of various kind of consumers. There are eleven (12) comparison of researchers and country over the world such as ICSC Canada (2004), [17], [5], [12], [16], [8], Singapore, ICSC Pan Asia, Thailand, Indonesia, ICSC Asia Pacific and Malaysia. The categories are size, location, anchor tenants, type of product, concept and design which each part serves different definition. Through this comparison, the most frequency of criteria will be used in a classification model of shopping centres in Malaysia. Table 2 illustrates the comparison of shopping centre classification by countries and researchers. Based on the categories comparison, there are ten (10) classes of a shopping centre was identified including Super Regional, Regional, Neighbourhood, Hypermarket, Destination Retail Centre/ Retail Plaza, Factory Outlet Centre, Destination Retail Community Centre, Lifestyle Centre and Power Centre.

\section{METHODS}

This paper is to recognise the classes of shopping centres in Malaysia based on the attributes of each category as a preliminary study. To achieve the objective, the researchers was distributed the questionnaire to respondents consisting of government and private sector practitioners. The method was used for data collection is Delphi Method. 10 people were selected represented Property Management, Valuation, Estate Agency, Malaysia Shopping Mall Associates, Academician, Shopping Mall Property Division and
Government Body. The tenants and the retail customers will involve in second stage survey. There are three types of interview including structured interviews, semi-interviews and unstructured interview (Merriem, 1998). A semistructured interview was implemented in this study because it can describe what the respondent thinks, and it is flexible. The use of the interview guide allowed more structure, which in turn eased the researcher's task of organizing and analysing interview data. Each interview session took 30 minutes approximately. The respondents have more than 10 years' work experience in their

organisation. This research will come out the classification of shopping centre Model in Malaysia. This model will be using the different elements such as green elements as the criteria and its different with other countries.

\section{RESULTS}

Based on a literature review, comparison matrix on twelve (12) shopping centre in over the world, there are 10 types of shopping centre is suitable prevail in Malaysia. In fact, each country has different categories and classification of shopping centre. They have their own definitions and categories. The categories of shopping centre shows as per attachment. Analysis results showed a significant difference in the outcome of the methods. For each shopping centre comparison, there are six (6) criteria to be compared which are floor size (net \& gross), anchor tenants, variety of product, locational aspect, concept and configuration/ presentation/ design. The table below shows the very important criteria for each shopping centre categories

\begin{tabular}{|l|l|l|l|l|l|l|l|l|l|l|}
\hline $\begin{array}{l}\text { Criteri } \\
\text { a }\end{array}$ & $\begin{array}{l}\text { Super } \\
\text { Region } \\
\text { al }\end{array}$ & $\begin{array}{l}\text { Region } \\
\text { al }\end{array}$ & $\begin{array}{l}\text { Neighb } \\
\text { ourhoo } \\
\mathrm{d}\end{array}$ & $\begin{array}{l}\text { Comm } \\
\text { unity } \\
\text { Centre }\end{array}$ & $\begin{array}{l}\text { Hyper } \\
\text { market }\end{array}$ & $\begin{array}{l}\text { Lifestyl } \\
\text { e } \\
\text { Centre }\end{array}$ & $\begin{array}{l}\text { Retail } \\
\text { Podium } \\
\text { /Plaza }\end{array}$ & $\begin{array}{l}\text { Power } \\
\text { Centre }\end{array}$ & $\begin{array}{l}\text { Factory } \\
\text { Outlet } \\
\text { Centre }\end{array}$ & $\begin{array}{l}\text { Niche/ } \\
\text { Destina } \\
\text { tion } \\
\text { Retail }\end{array}$ \\
\hline Size & $20 \%$ & $30 \%$ & $10 \%$ & $20 \%$ & $30 \%$ & $10 \%$ & - & $10 \%$ & $20 \%$ & $40 \%$ \\
\hline $\begin{array}{l}\text { Anchor } \\
\text { tenants }\end{array}$ & $20 \%$ & $20 \%$ & $40 \%$ & $10 \%$ & $40 \%$ & $10 \%$ & - & $20 \%$ & & $20 \%$ \\
\hline $\begin{array}{l}\text { Types } \\
\text { of } \\
\text { product }\end{array}$ & $60 \%$ & $50 \%$ & $40 \%$ & $30 \%$ & $40 \%$ & $30 \%$ & $40 \%$ & $40 \%$ & $70 \%$ & $20 \%$ \\
\hline $\begin{array}{l}\text { Locatio } \\
\mathrm{n}\end{array}$ & $70 \%$ & $80 \%$ & $50 \%$ & $50 \%$ & $50 \%$ & $60 \%$ & $10 \%$ & $30 \%$ & $40 \%$ & $40 \%$ \\
\hline $\begin{array}{l}\text { Concep } \\
\mathrm{t}\end{array}$ & $60 \%$ & $40 \%$ & $40 \%$ & $20 \%$ & $40 \%$ & $40 \%$ & $20 \%$ & $30 \%$ & $30 \%$ & $20 \%$ \\
\hline $\begin{array}{l}\text { Config } \\
\text { uration/ } \\
\text { present } \\
\text { ation } \\
\text { /design. }\end{array}$ & $50 \%$ & $60 \%$ & $20 \%$ & $20 \%$ & $30 \%$ & $50 \%$ & $20 \%$ & $40 \%$ & $10 \%$ & $50 \%$ \\
\hline
\end{tabular}

For the super-regional details of location must be situated on mass transit lines (e.g. subway, LRT, bus and city centre), for regional located in downtown areas of major metropolitan markets, for the neighbourhood must be near to the residential and neighbourhood area, and community centre located in any urban area or central business district near residential area and located in an residential neighbourhood, residential areas, edge or out of town.
Criteria of types of product (selling surplus stock, priorseason or slow selling merchandise and especially designed merchandise) and concept (manufacturers' and retailers' outlet stores selling brand name goods at a discount) treat as very important $(70 \%)$ by respondents for factory outlet

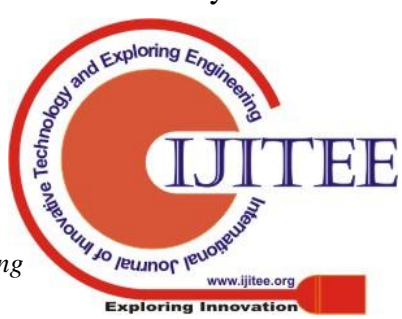




\section{TOWARDS FIVE STAR CLASSIFICATION SHOPPING CENTRE IN MALAYSIA: AN EXPLORATORY RESEARCH ON CATEGORIES OF SHOPPING CENTRE}

categories. Besides that, the categories of retail podium/plaza presented the highest percentage very important of types of products (retail offer is usually limited to $\mathrm{F} \& \mathrm{~B}$, services, office supplies). Most respondents agreed configuration/ presentation/ design (wholesale/retail) is very important $(50 \%)$ for niche/destination retail categories. In response to power centre, there are $40 \%$ the highest percentage of very important for types of product (large big box stores and wholesale clubs) and configuration/ presentation/ design (consistently designed, planned and managed scheme that comprises mainly medium and largescale specialist retailers).

\section{DISCUSSION}

Finally, based on this study, it can be concluded that the result shows location is very important criteria especially in categories of regional, super-regional neighbourhood, community centre and hypermarket. Respondents agreed location is the most crucial factor for investing in real estate since the age-old punch line "Location, Location, Location" still rules and remains the most important factor for profitability in real estate investment. [13] states the main success of shopping centre is the location. Accessibility also need to be consider as features including distance to the facilities/ utilities, travel time, geographic boundaries or population within the catchment. Customers will go to a shopping centre if easily accessible and easy to reach. Respondents also agreed size as one of the critical criteria because they classified the shopping centre in Malaysia based on size. They have their own definition/ classification for their research purpose. They only cover the large scale of shopping centre such as mega mall and hypermarket and not cover the arcade. The reason is arcade is a small scale and not give the attraction to investors. Shopping centre size have linear relation with the variety of goods and service as their basic assumption by [1]. The bigger of shopping centre means more attraction for shoppers. The balance between product variety and size of shopping centre will provide more comfortable shopping centre [14]. Respondent state anchor tenant and tenant mix also crucial and need to balance with the presentation and ambiance of shopping centre to attract the customers. [15] was detailed five important features as attraction influence of shopping centre which are location, business concept, design, tenant mix, and lastly management. In short, this shopping centre classification model can be advancement benchmarking for Malaysian commercial property when all is said in done.

\section{ACKNOWLEDGMENTS}

This work is funded by Construction Research Institute of Malaysia (CREAM), CIDB, University Technology Mara (UiTM) Shah Alam and University Tun Hussein Onn Malaysia (UTHM). The researchers would like to thank the relevant parties that have directly or indirectly contributed to the accomplishment of this research. Besides, the researchers wish to offer their thanks to the mysterious referees for their accommodating remarks and various amendments to enhance this paper.

\section{REFERENCES}

1. Carn, N., Rabianski, J., Racster, R., Seldin, M., 1988. Real Estate Market Analysis Technique and Applications, Prentice Hall, New Jersey

2. Colavolpe, A, 2010. Demystifying the Corporate real Estate Process: The Retailer's Perspective. Real Estate Issues, 35 (1), $14-19$.

3. CNN, 2014. World's 12 best shopping cities. A report http://edition.cnn.com/2013/11/18/travel/worlds-bestshopping-cities/index.html

4. Gaya Travel Magazine, 2012. Retrieved by http://www.gayatravel.com.my/musa-yusof-directordomestic-marketing-division-tourism-malaysia/

5. Hines M. A, 1983. Shopping center development and investment. John Wiley \& Sons, New York.

6. International Council of Shopping Centers (ICSC), 2004 Shopping Center Definitions. Retrieved on March 25th, 2015 via website http://www.icsc.org/research/references/c-shoppingcenter-definitions

7. James Tee, 2016. "Malaysian Real Estate Industry", Value Creation Strategies. A book.

8. Konishi, H. and Sandfort, M.T, 2003. Anchor stores. Journal of Urban Economics 53: 413-435

9. Merriam, S. B, 1998. "Qualitative Research and Case Study Application in Education.” San Francisco: Jossey Bass. hlm. 26 - 43.

10. National Transformation Programme Annual Report, 2015.

.https://www.pemandu.gov.my/assets/publications/annual -reports/NTP_AR2016_ENG.pdf

11. National Property Information Center (NAPIC), 2012 Existing stock for residential, commercial, leisure and industrial property sub-sector as at Q1-Q4 2014.

12. Raine and Home International Zaki and Partners Sdn.Bhd, 2005. Trend of shopping centre developments in greater Klang Valle towards 2005. Kuala Lumpur: Raine, Horne International Zaki and Partners Sdn. Bhd

13. Syahara, H., Ristiana, V., 1992. "KiatSukses Shopping CenterLokasi, Lokasi, danLokasi, Info Papan, April, pp 13-15.

14. Susilawati.C, SutotoYakobusAnd Lenny Sulistyawati, 2002." The Influence Of Travel Time And Size Of Shopping Center Towards The Frequencies Of Visiting Customers In Shopping Centers In Surabaya". 8 th PRRES Conference.

15. Tanan, A, 1998. "ManajemenPusatPerbelanjaan (Shopping Center Management)", guest lecture note, Postgraduate Program, Petra Christian University, Surabaya

16. UngkuSuseelawati Omar (DTZ Debenham Tie Leung) and Michael Baker (Independent Retail Consulting), 2009. First Steps Toward a Shopping Center Typology for Southeast Asia, Asia-Pacific and Beyond.

17. U.S. Shopping-Center Classification and Characteristics, 2009. International Council of Shopping Centers (ICSC). (Research)

18. Yusof.H, 2011. Location and Typology of Shopping Centres as Catalyst for Economic Growth. World Applied Science Journal 13 (Special Issue of Human Dimensions of Development). 23-28. ISSN 1818-4952 


\section{AUTHORS PROFILE}

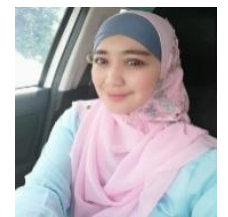

Ihfasuziella Ibrahim is a Ph.D Student at Faculty of Architecture, Planning and Surveying, UniversitiTeknologi Mara. Her main research interest is Facility Management.

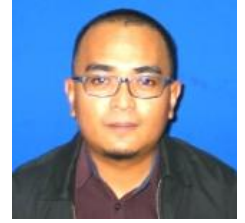

Dr. Edie EzwanMohdSafianis a lecturer at Faculty of Technology Management and Business, UniversitiTun Hussein Onn Malaysia. His area of research interest includes Building Performance Assessment, Geo-information System and Decision-making Tools. 